\title{
Seasonal occurrence and sexual segregation of great white sharks Carcharodon carcharias in Mossel Bay, South Africa
}

\author{
Hannah R. Milankovic • Nicholas D. Ray (D) • Louise K. \\ Gentle • Christo Kruger • Esther Jacobs • Craig J. \\ Ferreira
}

Received: 2 July 2020 / Accepted: 19 April 2021 / Published online: 3 May 2021

(C) The Author(s) 2021

\begin{abstract}
The seasonal occurrence and temporal sexual segregation of great white sharks Carcharodon carcharias have been widely documented in various temperate and sub-tropical waters across the globe. Yet, there is limited understanding of the relationship between the life stages and habitat use of $C$. carcharias, particularly in the Southern Cape. In this study, we investigated the population dynamics of $C$. carcharias in Mossel Bay, South Africa, between 2009 and 2013, using skipper logbooks and citizen research data obtained by a cage-diving vessel. A total of 3064 sharks, ranging in life history stages from young-of-the-year to subadult, were sighted during 573 trips. Juveniles dominated the sightings throughout the study, and there was marked sexual segregation, with females dominating the total sightings of sharks. C. carcharias were most abundant during the cooler, winter season, with females differing in abundance seasonally and males maintaining a low abundance throughout the year but peaking in
\end{abstract}

H. R. Milankovic • N. D. Ray $(\bowtie) \cdot$ L. K. Gentle

School of Animal, Rural and Environmental Sciences,

Nottingham Trent University, Brackenhurst Campus, Southwell,

Nottinghamshire NG25 0QF, UK

e-mail: nicholas.ray@ntu.ac.uk

C. Kruger - C. J. Ferreira

White Shark Africa, PO Box 2979, Mossel Bay 6500, South Africa

E. Jacobs

Keep Fin Alive, 3 Jason Jon's Place, Mossel Bay 6500, South Africa the winter. In addition, sea surface temperature was the best indicator of $C$. carcharias presence. Abundance was greatest when vertical water visibility exceeded $3 \mathrm{~m}$, with cloud cover influencing overall abundance negatively. Likely reasoning for the aggregation of C. carcharias in Mossel Bay includes the favourable conditions and abundance of food. Juvenile sharks may also utilise this area as a training ground to learn from larger conspecifics. This research demonstrates that information on population size and structure of C. carcharias can be obtained effectively through a compilation of logbook and citizen science data to assess and identify potential critical habitats in the quest to develop appropriate management strategies. This research also shows value in commercial cage-diving operations deriving international data sets needed to assess global populations of $C$. carcharias.

Keywords Population dynamics · Ecotourism · Logbooks $\cdot$ Juvenile $\cdot$ Nursery ground $\cdot$ Social learning

\section{Introduction}

Identifying critical habitats for wildlife offers the development of appropriate management strategies (Simpfendorfer et al. 2011). However, such research requires information on movement patterns (Speed et al. 2010; Simpfendorfer et al. 2011) and site fidelity of species (Knip et al. 2012). Great white sharks Carcharodon carcharias are highly migratory, apex predators, distributed throughout temperate and 
subtropical coastal ecosystems (Compagno 1991; Bonfil et al. 2005; Domeier and Nasby-Lucas 2012). The major regions of abundance occur in the coastal waters of California, Mexico, Australia, New Zealand and South Africa (Ferreira and Ferreira 1996; Compagno 2001; Anderson and Pyle 2003; Robbins 2007; Jorgensen et al. 2010). Their extensive distribution within coastal waters makes $C$. carcharias susceptible to disruptive anthropogenic activities, such as fisheries, pollution and shark control programs (Bruce and Bradford 2012; Kock et al. 2013; Dulvy et al. 2014). In addition, the life history of this species, characterised by low fecundity (Uchida et al. 1996), slow growth (Wintner and Cliff 1999) and late maturity (Francis 1996), demonstrates high intrinsic vulnerability to overexploitation (Smith et al. 1998; Stevens et al. 2000; Dulvy et al. 2008, 2014; Rigby et al. 2019).

Through advances in acoustic and satellite telemetry, it is known that $C$. carcharias take extensive migrations before demonstrating site fidelity at coastal aggregations (Pardini et al. 2001; Boustany et al. 2002; Bonfil et al. 2005; Bruce et al. 2006; Weng et al. 2007; Domeier and Nasby-Lucas 2008; Jorgensen et al. 2010, 2012; Bruce and Bradford 2012). Consequently, the degree of site fidelity is believed to have a strong influence on the species' exposure to disruptive anthropogenic activities (Bruce and Bradford 2012; Dulvy et al. 2014).

Seasonal variations and consequent changes in environmental parameters greatly influence C. carcharias abundance, segregation and activity (Pyle et al. 1996; Martin et al. 2005; Hammerschlag et al. 2006; Robbins 2007; Kock et al. 2013; Towner et al. 2013), and individuals of different sizes and life stages are likely to have a varied tolerance to abiotic factors (Hussey et al. 2012; Kock et al. 2013). For example, White et al. (2019) reported that juvenile C. carcharias abundance in Southern California Bight was highest when water temperatures were greater than $19{ }^{\circ} \mathrm{C}$. Sexual segregation of sharks can occur due to differences in age, habitat selection and nutritional requirements (Magurran and Garcia 2000; Wearmouth and Sims 2008). Anderson and Pyle (2003) identified that female visitation to aggregation sites in California was linked to their gestation period (12-18 months), displaying biennial residency, whereas males visited annually. However, there is strong evidence to suggest that sexual segregation is not restricted to adult $C$. carcharias (Kock et al.
2013); thus, an understanding of habitat use of young-of-the-year (YOY), juvenile and subadult sharks is required.

Several studies have also demonstrated that C. carcharias foraging behaviour and predation is influenced by variations in ocean temperature (Weltz et al. 2013; Skubel et al. 2018), water visibility (Pyle et al. 1996; Hammerschlag et al. 2006), lunar phase (Fallows et al. 2016), tidal height and swell (Anderson et al. 1996; Pyle et al. 1996). There is strong evidence to suggest that low ambient light and poor water visibility increase C. carcharias stealth resulting in successful predation upon pinnipeds at the surface (Strong et al. 1992; Pyle et al. 1996; Hammerschlag et al. 2006).

Despite their circum-global distribution (Boustany et al. 2002; Bonfil et al. 2005; Weng et al. 2007; Domeier and Nasby-Lucas 2008; Jorgensen et al. 2010), C. carcharias aggregation sites are typically associated with pinniped colonies (Compagno et al. 1997; Goldman and Anderson 1999; Bruce et al. 2005), particularly within South Africa (Ferreira and Ferreira 1996; Johnson 2003; Martin et al. 2005; Fallows et al. 2012; Jewell et al. 2013; Towner et al. 2013; Ryklief et al. 2014). For example, adult and subadult $C$. carcharias often undertake offshore migrations, likely due to seasonal prey availability and possible mating opportunities (Bonfil et al. 2005; Dudley 2012). Consequently, reports have revealed that $C$. carcharias sighted at pinniped colonies appear to be either largely transient or temporarily absent, which is defined as returning after an absence of one or more years (Hewitt et al. 2017), with a few long-term residents occupying the area for consecutive years (Strong et al. 1992; Klimley and Anderson 1996). In contrast, in False Bay, South Africa, C. carcharias are resident throughout the year, but their abundance is directly influenced by the seasonal presence of young cape fur seals Arctocephalus pusillus pusillus. It has been suggested that in the absence of adolescent seal pups, C. carcharias undergo a dietary shift and prey upon summer fish species such as yellowtails Seriola lalandi and bronze whale sharks Carcharhinus brachyurus which are located closer to the shore (Martin et al. 2005). Ontogenetic dietary changes in sharks are caused by a shift in foraging behaviour and habitat use (Tricas and McCosker 1984; Hussey et al. 2012; Kim et al. 2012). This can be evidenced by social learning and physical maturation (Meyer 1986; 
Ciaccio 2008; Guttridge et al. 2009, 2012; Pouca et al. 2020). Therefore, the foraging behaviours and habitat utilisation of juvenile $C$. carcharias may differ to that of older conspecifics (Carlisle et al. 2012; French et al. 2018; Tamburin et al. 2019).

In Australian waters, Malcolm et al. (2001) noted there was a tendency for juveniles to occur in different areas to subadults and adults, with juveniles more commonly encountered in inshore areas, often in the vicinity of open coast beaches. Currently it is not known what stimulates $C$. carcharias to drastically change a life history pattern that keeps them near the continental shelf as juveniles to another that leads them seasonally into a deep pelagic habitat (Domeier and Nasby-Lucas 2012). Nevertheless, Kock (2014) found no difference in residency periods between small or large sharks, or between males and females, or any sex or size-based segregation, at Seal Island in False Bay, South Africa. In fact, sharks of both sexes and a range of sizes were often recorded on a single day, although not always at the same time.

The movement patterns and seasonal abundance of individuals among aggregation sites have largely been identified using a variety of telemetry and visual identification methods. However, an invaluable source of data is derived from logbooks used by permitted marine tourism operators (Malcolm et al. 2001; Bonfil et al. 2005; Johnson and Kock 2006; Jewell et al. 2013; Towner et al. 2013) to monitor shark C. carcharias populations. The potential for shark-watching ecotourism as a vehicle for collecting scientific data on the status of shark populations has been recognised by researchers in several countries as an optimum, long-term method of data collection which has minimal delay (Malcolm et al. 2001; Theberge and Dearden 2006; Meyer et al. 2009). Mossel Bay, South Africa, is one such location of shark-watching ecotourism that provides an excellent inshore region for a plethora of $C$. carcharias population investigations.

This study aims to utilise logbook data to investigate the seasonal occurrence and sexual segregation of C. carcharias occupying Mossel Bay over a 5-year period, to understand the habitat preferences of different life-stages. This is important because it will help to ascertain whether Mossel Bay is a critical habitat for particular life stages and if this habitat requires conservation management to facilitate the sustainability of the population.

\section{Materials and methods}

Study site

Mossel Bay ( $\mathrm{S}^{\prime} 34^{\circ} 10, \mathrm{E}^{\prime} 22^{\circ} 10$, Fig. 1) is a semiclosed bay that lies approximately $400 \mathrm{~km}$ to the east of Cape Town and is situated centrally within the Agulhas marine bioregion on the southern Cape coast of South Africa (Gubili et al. 2009). The bay encloses three estuaries, Kleinbrak, Grootbrak and Hartenbos, which hosts a diverse ecosystem with many estuarinedependent marine species (James and Harrison 2008; Johnson et al. 2009a, b). A notable feature within the bay is Seal Island $\left(S^{\prime} 34^{\circ} 09, E^{\prime} 22^{\circ} 07\right.$ ), which consists of a rocky outcrop located approximately $700 \mathrm{~m}$ off the East coast (Gubili et al. 2009) and is host to a cape fur seal Arctocephalus pusillus pusillus colony of approximately 4500-5000 individuals (Jewell et al. 2013). The bay is relatively shallow $(\sim 20 \mathrm{~m})$ with a flat seabed consisting of exposed reefs and sand (Johnson et al. $2009 \mathrm{a}, \mathrm{b}$ ) and is partially protected from prevailing winds from the south west by the peninsula, resulting in a calm bay ideal for tourism and study (Levy 2016).

\section{Data collection}

Data collection was conducted onboard 'Shark Warrior', a shark cage-diving vessel previously owned by White Shark Africa and currently the only commercial dive operator in Mossel Bay. During each outing, the vessel anchored at Seal Island $\left(\mathrm{S}^{\prime} 34^{\circ} 09, \mathrm{E}^{\prime} 22^{\circ} 07\right)$, and the anchoring position and depth were recorded using the vessel's Furuno NavNet VX2 equipment. Approximately $5 \mathrm{~kg}$ of chum consisting of sardine oils and seawater, creating an attractant to Carcharodon carcharias (Strong et al. 1992), was deployed during each outing. As C. carcharias naturally aggregate in this area, individuals were occasionally observed at the anchor site prior to using any attractant; however, the chum was initiated to attract $C$. carcharias closer to the boat and aid with shark identification. Data collection took place during the full period on the shark observation trip which notably lasted $3 \mathrm{~h}$ per time.

The number of individual sharks sighted on each trip was estimated by experienced observers on deck, based on markings on the shark's body, estimated size, sex and presence of any tags recorded on ID sheets. A counted observation was based on the amount of time an individual was in proximity to the boat or interacted with the 


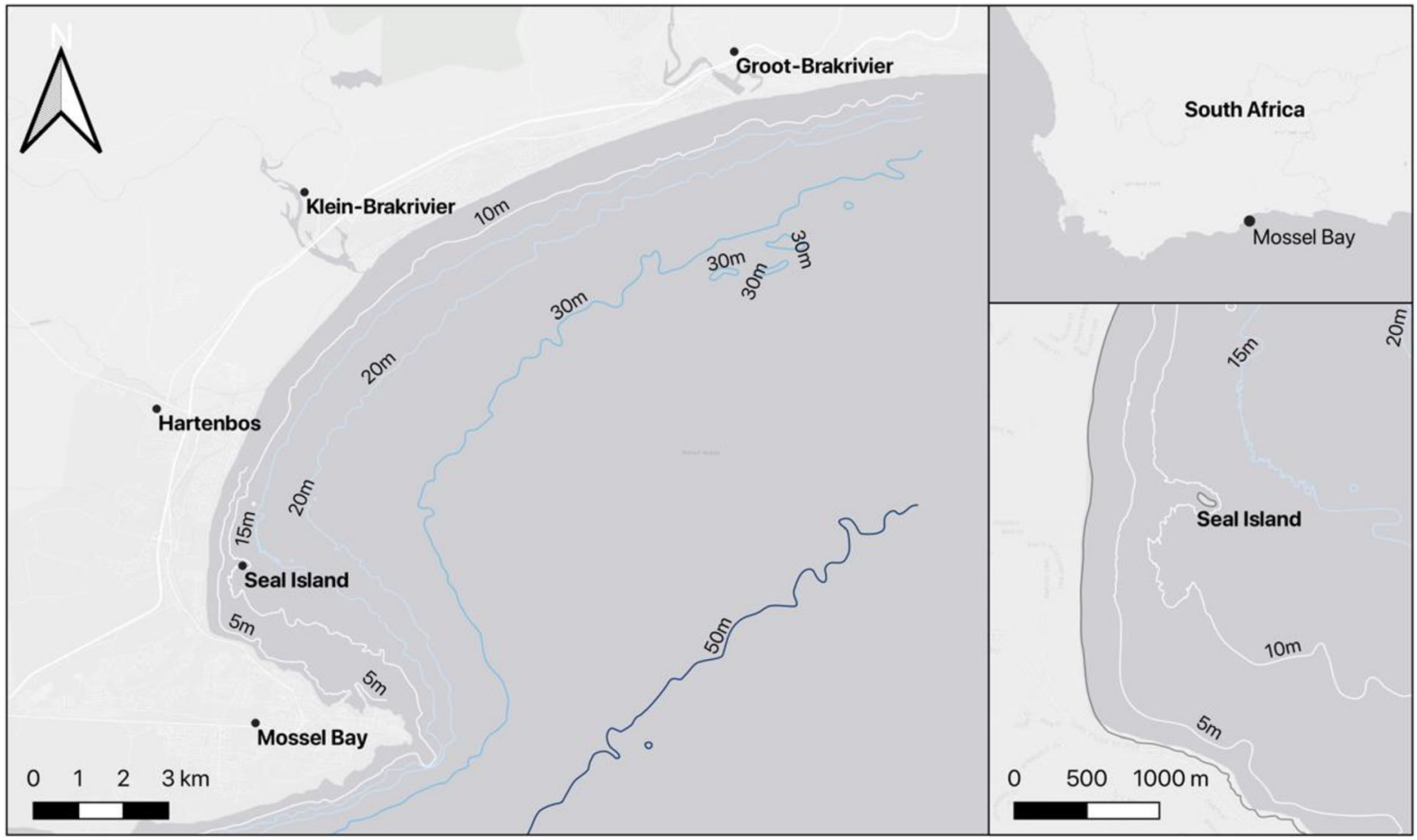

Fig. 1 Map of Mossel Bay, showing Seal Island, and the inset map of Mossel Bay on the South African coast. Contour lines indicate depth in metres

bait. If an individual was present for over one minute, it was classed as one observation. The sex of each shark was recorded based on the presence or absence of claspers within the pelvic area, determined by both surface and underwater observations. Individuals that could not be sexed were recorded as unknown. Shark total length (TL) was estimated to the nearest $0.1 \mathrm{~m}$ against known dimensions of the shark cage, following Jorgensen et al. (2010), Kock et al. (2013) and Towner et al. (2013). Individuals were categorised into size class, as proposed by Bruce and Bradford (2012): YOY $(<1.75 \mathrm{~m})$, juvenile $(1.75-3.0 \mathrm{~m})$, subadult male (3.1-3.6 m), subadult female (3.1-4.8 m), adult male (> $3.6 \mathrm{~m})$ and adult female $(>4.8 \mathrm{~m})$. Individuals were identified based on visible scars, bite wounds, fin notches and coloration, all of which were drawn on physical characterisation data sheets in order to prevent miscounting and an overestimation of shark observations. This information was logged during each trip to provide baseline assessments of species composition and relative abundances, which can yield insights into seasonal cycles and presence in relation to environmental parameters (Theberge and Dearden 2006; Nazimi et al. 2018). A combination of experienced spotters, both on the boat and in the shark-viewing cage, assisted in eliminating any potential errors associated with poor vertical and horizontal water visibility with C. carcharias sightings.

\section{Environmental variables}

Sea surface temperature (SST), water temperature at $10 \mathrm{~m}$, cloud cover and vertical water visibility were recorded on anchoring the research vessel, as each variable has been suggested to influence relative abundance of C. carcharias (Pyle et al. 1996; Martin et al. 2005; Hammerschlag et al. 2006; Jewell et al. 2013; Kock et al. 2013). SST (measured to the nearest $0.5^{\circ} \mathrm{C}$ ) was recorded manually using a thermometer placed approximately $2 \mathrm{~m}$ into the water column. In instances whereby SST was not recorded, monthly averages were obtained from the NASA Giovanni portal (http://disc.sci.gsfc. nasa.gov/giovanni) covering an area of $490 \mathrm{~km}^{2}$ in Mossel Bay from the peninsula to Grootbrak river. Water temperature at $10 \mathrm{~m}$ was recorded at a depth of $10 \mathrm{~m}$, using the same method for SST. Vertical water visibility (measured to the nearest $0.2 \mathrm{~m}$ ) was recorded 
using a Secchi disk, and cloud cover was recorded to the nearest $5 \%$ using human observation.

Data analysis

A Poisson regression analysis was undertaken on the number of $C$. carcharias sighted per trip, with season and sex as categorical predictors, plus interactions between the terms. In addition, a linear regression analysis was undertaken on $C$. carcharias size, with season and sex as categorical predictors, plus interactions between the terms. Individuals of unknown sex were omitted from analyses but have been presented in figures for comparison.

A generalised additive model (GAM) with a negative binomial distribution and a log link function was undertaken on the number of $C$. carcharias sighted per trip, with SST, cloud cover and vertical water visibility as continuous predictors, as the relationship between the response and predictor variables was non-linear. Cubic regression splines were restricted to a maximum of four degrees of freedom. Data were explored following Zuur et al. (2012), and water temperature at $10 \mathrm{~m}$ was omitted from the model due to collinearity with SST. Analyses were initially performed using Minitab version 18.2, with further analyses undertaken using RStudio Version 1.2.5001 with the "gam" and "mgev" packages (Wood 2011).

\section{Results}

Over the 5-year study period, 573 cage-diving trips were made to Mossel Bay (Table 1). A total of 3064 Carcharodon carcharias were sighted in the Mossel Bay region, ranging in size from 1.1 to $4.0 \mathrm{~m}$. The majority of $C$. carcharias sightings were females (56.9\%) and unsexed individuals, with males making up only $6.9 \%$ of sightings (Fig. 2). Juveniles dominated the demographic structure $(81.1 \%)$, and the remaining sightings were primarily subadults, as YOY made up $<1 \%$ of $C$. carcharias, and no adult C. carcharias were identified in this study.

Abundance and seasonal variation

Significantly more females than males were sighted per trip in Mossel Bay $\left(\chi^{2} 1,1138=245.68\right.$, $p<0.001)$. In addition, there were significantly more $C$. carcharias sighted per trip during the winter season (June-August) $\left(\chi^{2} 3,1138=46.34, p<0.001\right.$; Fig. 2). There was also a significant interaction between sex and season, whereby the number of females sighted per trip was highest in winter and differed significantly each season, but the number of males sighted per trip was only significantly different (higher) during the winter $\left(\chi^{2} 3,1138=46.11\right.$, $p<0.001$; Fig. 2). Unsexed C. carcharias were sighted more frequently than males throughout the seasons, with highest abundance in the winter months (Fig. 2).

Size and seasonal variation

Female $C$. carcharias were significantly larger than males $\left(F_{1,1946}=24.45, \mathrm{p}<0.001\right)$. There was no effect of season on the size (TL) of $C$. carcharias present at the study site $\left(F_{3,1946}=3.31, p=0.069\right)$, although there was a significant interaction between sex and season, whereby smaller males were sighted more frequently during the summer, smaller females were sighted more frequently during the autumn, and larger females were sighted more frequently during the winter $\left(F_{3,1946}=3.67, p=0.012\right.$, Fig. 3$)$. The size of unsexed $C$. carcharias remained relatively constant throughout the year, with smaller individuals sighted during the autumn, and larger C. carcharias sighted in the winter months (Fig. 3).

Abundance and environmental variables

Sea surface temperature and vertical water visibility had a significant effect on $C$. carcharias abundance (SST: $\mathrm{z}=17.78, p<0.001$; vertical water visibility: $\mathrm{z}=2.16, p<0.05$ ), with SST being the most influential variable (adjusted R-squared $=13.3 \%$; Fig. 4). Findings revealed that $C$. carcharias abundance decreased when SST rose, with abundance showing least variation around $16-18{ }^{\circ} \mathrm{C}$ and peaked at a vertical water visibility of $5 \mathrm{~m}$ (Fig. 4). Although not significant $(\mathrm{z}=-1.83, p=0.067)$, it was observed that cloud cover had a negative effect on C. carcharias abundance with greatest sightings recorded when cloud cover was lower than $70 \%$ (Fig. 4). 
Table 1 Summary of trips per month and total sightings of C. carcharias between November 2009 and February 2013 in Mossel Bay, South Africa

\begin{tabular}{llll}
\hline Month & Season & Total number of trips & Total shark sightings \\
\hline January & Summer & 42 & 260 \\
February & Summer & 52 & 204 \\
March & Autumn & 43 & 151 \\
April & Autumn & 36 & 111 \\
May & Autumn & 41 & 221 \\
June & Winter & 64 & 451 \\
July & Winter & 56 & 429 \\
August & Winter & 41 & 324 \\
September & Spring & 35 & 241 \\
October & Spring & 35 & 130 \\
November & Spring & 81 & 333 \\
December & Summer & 47 & 209 \\
Total & & $\mathbf{5 7 3}$ & $\mathbf{3 0 6 4}$ \\
\hline
\end{tabular}

\section{Discussion}

Abundance and size

Mossel Bay was dominated by sightings of juvenile Carcharodon carcharias throughout the study period. This is in agreement with Strong et al. (1996), who suggest that smaller sharks limit their spatial use to reduce interactions with larger conspecifics. This is further supported by Ryklief et al. (2014), who observed a large proportion (78\%) of juvenile $C$. carcharias in Mossel Bay, suggesting that these individuals prefer sheltered conditions which may serve to increase their rates of growth and development, and to avoid predation (Branstetter 1990; Heupel et al. 2007). There was also a high predominance of sightings of female

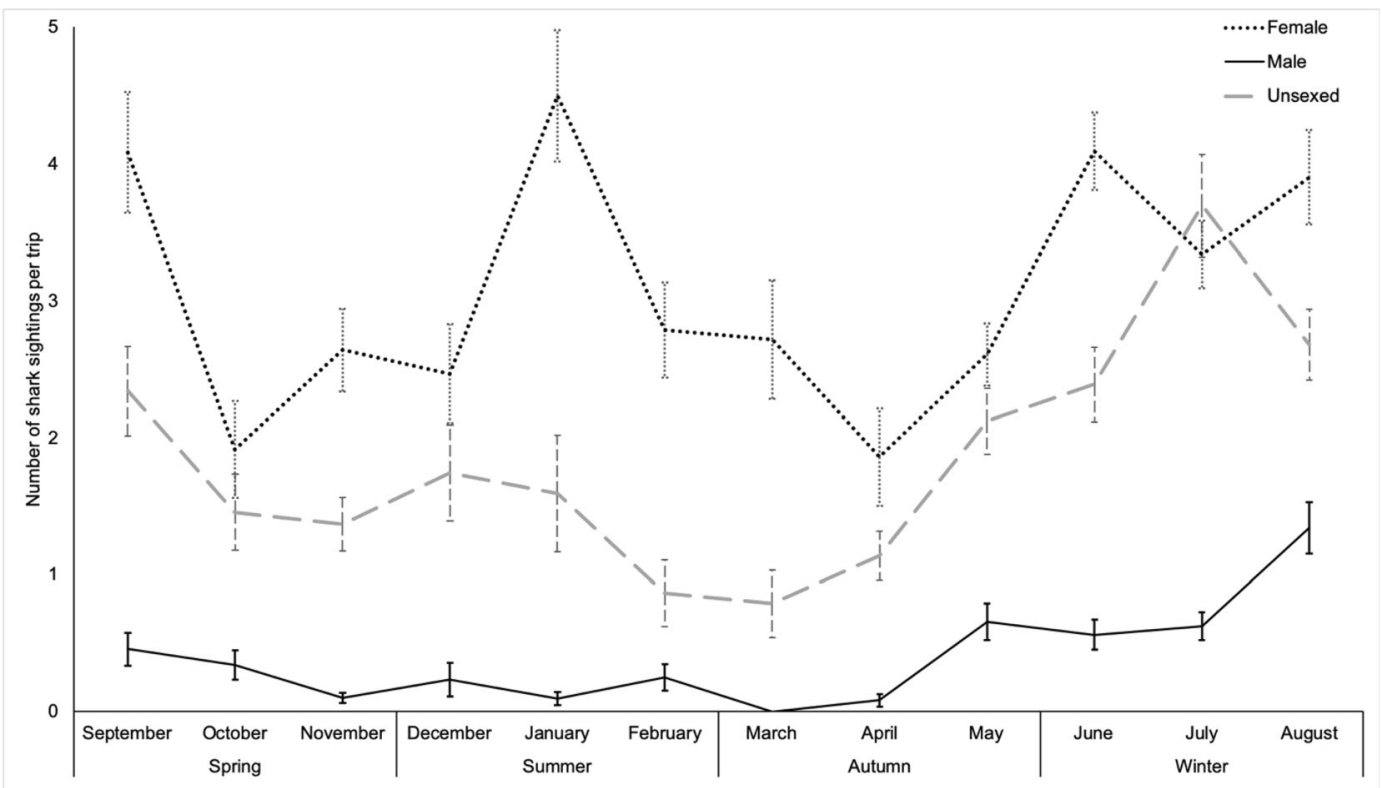

Fig. 2 Average (mean $\pm \mathrm{SE}$ ) number of male, female and unsexed C. carcharias per month and season in Mossel Bay, South Africa from 2009 to 2013 


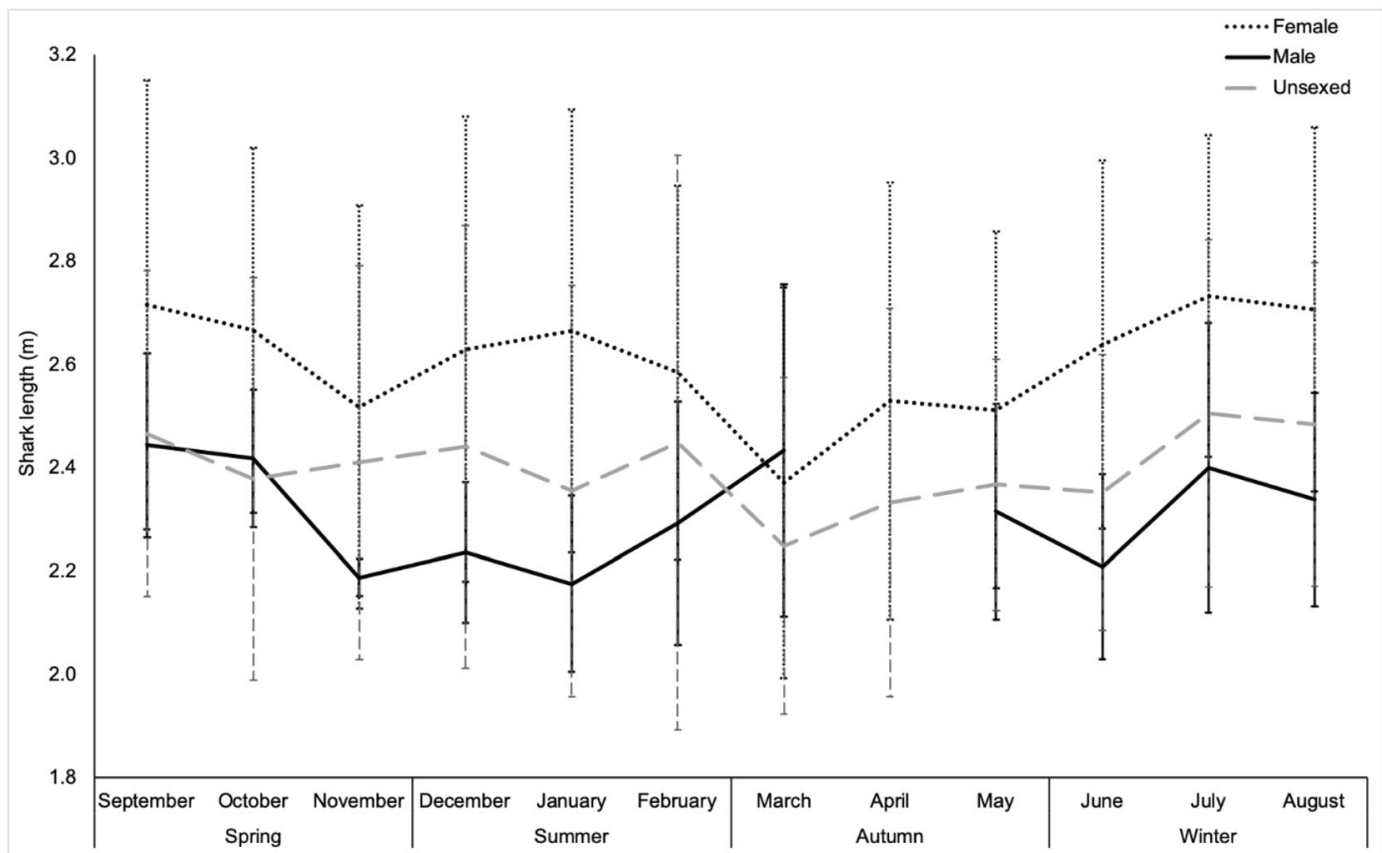

Fig. 3 Average (mean \pm SE) length of male, female and unsexed C. carcharias per month and season in Mossel Bay, South Africa from 2009 to 2013
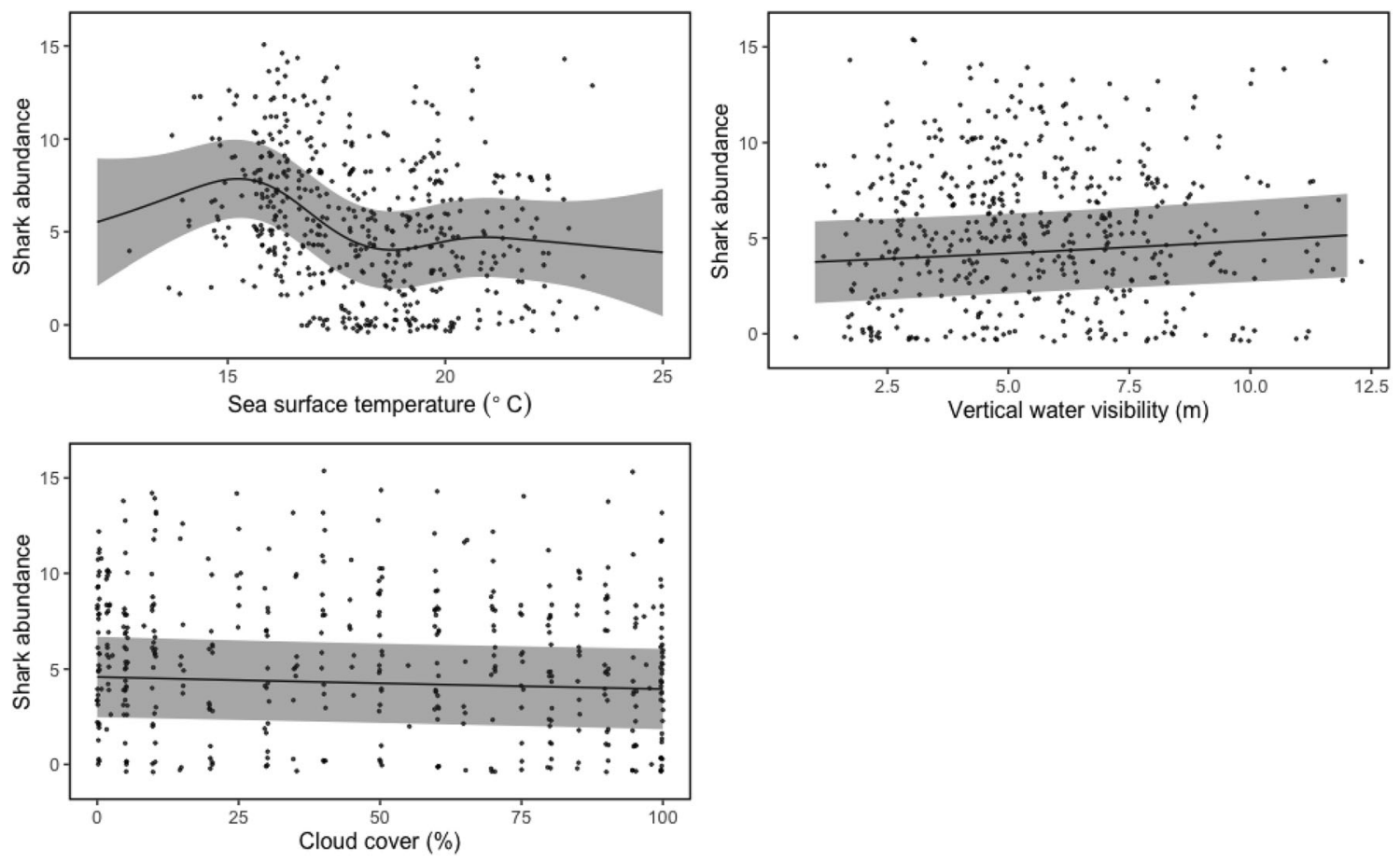

Fig. 4 Response plots from generalised additive model (GAM) of environmental variables relative to the presence-absence of C. carcharias in Mossel Bay, South Africa. Estimated smooth

functions (solid lines) with 95\% confidence interval (shaded area) are shown for each explanatory variable 
C. carcharias, whereas male presence was relatively low (Fig. 2), consistent with findings at other seal colonies in South Africa (Cliff et al. 1996; Ferreira and Ferreira 1996; Martin et al. 2005; Fallows et al. 2012; Towner et al. 2013; Ryklief et al. 2014; Hewitt et al. 2017). These findings are similar to Findlay et al. (2016), who identified that $74 \%$ of individuals in Mossel Bay were juvenile females. Despite an equal sex ratio at birth (Bruce 2008), high female abundance throughout the year is a common observation in the Southern Cape (Cliff et al. 1996; Towner et al. 2013, 2016; Kock et al. 2013; Hewitt et al. 2017). It is possible that females commonly inhabit the inshore areas, either due to competitive exclusion (Klimley et al. 2001), with larger sharks feeding at sites elsewhere, or to avoid mating harassment (Sims et al. 2001).

The co-occurrence of both sexes throughout the year has been recorded at several locations (Ferreira and Ferreira 1996; Kock and Johnson 2006; Robbins and Booth 2012; Towner et al. 2013, 2016; Kock 2014) and is suggested to be due to shelter, mating opportunities and prey availability. Indeed, Mossel Bay provides sheltered conditions that remain relatively stable throughout the year (Jewell et al. 2013). However, it is unlikely that mating opportunities are an explanation for the occurrence of both sexes in Mossel Bay, as no sharks were large enough to be sexually mature (Fig. 3). This is further supported by Ryklief et al. (2014) and Findlay et al. (2016) who recorded a low number of sexually mature individuals and YOY in the Mossel Bay area. Interestingly, during the winter, there is an abundance of adolescent Arctocephalus pusillus pusillus in Mossel Bay (Johnson et al. 2009a). Juvenile C. carcharias feed primarily on teleosts and small elasmobranchs before they exhibit an ontogenetic shift in prey preferences (Ainley et al. 1985; Klimley 1985; Hubbell 1996; Jorgensen et al. 2010; Kim et al. 2012). Therefore, despite the fact that juvenile $C$. carcharias predominantly prey on fish, $C$. carcharias are clearly attracted to Mossel Bay during the winter season, likely due to the abundance of vulnerable pinnipeds in the area. Indeed, males and larger (i.e. older) females, as well as unsexed individuals, were sighted more frequently during the winter months (Fig. 3) indicating that they are on the cusp of their ontogenetic shift in prey preferences and likely honing their predatory skills on inexperienced, adolescent seals (Dicken and Booth 2013).

It has been demonstrated that sharks have the potential for social learning within an association which allows individuals to acquire locally adaptive information (Guttridge et al. 2009, 2012; Pouca et al. 2020). It is possible that the high concentration of juvenile C. carcharias in Mossel Bay is observing larger conspecifics and their interactions with prey in which the younger individual learns something (Guttridge et al. 2012). Interestingly, Hammerschlag et al. (2006) observed C. carcharias between 2.2 and $4.6 \mathrm{~m}$ TL predating upon seals in False Bay, South Africa. This indicates that predation is not entirely limited to subadult $C$. carcharias in Mossel Bay, and juveniles may be taking advantage of social learning to facilitate predation before they exhibit changes in their own dietary preferences.

Heupel et al. (2007) defined a nursery area based on the criteria that (1) sharks are more commonly encountered in the area than other areas; (2) sharks have a tendency to remain or return for extended periods; and (3) the area or habitat is repeatedly used across years. Although YOY C. carcharias presence was low, they were still observed in the vicinity of Seal Island, and the high concentration of juvenile sharks in Mossel Bay throughout the study duration gives credence to the hypothesis that there is a potential nursery ground in the area. In addition, the co-occurrence of juvenile C. carcharias and adolescent seals in the area, particularly during the winter, provides ample opportunity for inexperienced sharks to use this site as a training ground. Juvenile sharks have been witnessed attacking seals in the area on several occasions by the authors during the observation trips. Consequently, Mossel Bay serves as critical habitat for the population of C. carcharias in the Cape indicating from the study that C. carcharias occupy this area throughout the year. It is therefore essential that this coastal habitat requires a full review of conservation management and it be implemented accordingly to ensure $C$. carcharias are not adversely impacted upon by anthropogenic activities (Heupel et al. 2007; Yates et al. 2012; Kock et al. 2013; Rigby et al. 2019).

\section{Seasonal variation}

C. carcharias have an extensive distribution encompassing several sites that they utilise for feeding (Bruce et al. 2005), suggesting seasonal migrations. It is recognised that $C$. carcharias distribution and segregation corresponds with seasonal changes in sea surface temperatures (Ainley et al. 1985; Abascal et al. 2011). 
As an endothermic species, $C$. carcharias is capable of tolerating varied temperatures across wide distributions (Graham 1983; Goldman 1997; Boustany et al. 2002). The water temperature in Mossel Bay varied seasonally from 13 to $23.5{ }^{\circ} \mathrm{C}$ during the study period and as expected was coolest during the winter season. More sharks, particularly males, were sighted during the cooler winter season, in agreement with previous studies where males were less common in warmer water (Figs. 2 and 4) (Robbins 2007; Robbins and Booth 2012; Dicken and Booth 2013; Kock et al. 2013; Towner et al. 2013). Although likely to vary between species, male sharks occupy waters of cooler temperatures for optimal sperm production (Kime and Hews 1982). However, given the predominance of juveniles present in Mossel Bay, it is unlikely that this is reasoning for males favouring cooler temperatures. The increase in juvenile $C$. carcharias sightings in colder waters in Mossel Bay is contrary to White et al. (2019) but does support other findings that juvenile C. carcharias are coastally associated. It is believed that indirect influences of water temperature such as prey availability and differing metabolism may affect C. carcharias abundance (Robbins and Booth 2012; Schlaff et al. 2014). As such, our findings suggest that although the abundance of inexperienced A. pusillus pusillus pups during the winter months is a controlling factor on C. carcharias distribution, the increase in sightings is also indirectly influenced by water temperature.

Vertical water visibility in Mossel Bay varied seasonally from 1 to $12 \mathrm{~m}$. A significant trend between C. carcharias abundance and vertical water visibility was observed in this study. Despite an increase in C. carcharias sightings with higher visibility, C. carcharias were most abundant when vertical water visibility was between 3 and $7 \mathrm{~m}$ (Fig. 4). Pyle et al. (1996) demonstrated that lower visibility is favourable for $C$. carcharias stalking ability and is assumed to be a learned tactic in larger sharks (Hammerschlag et al. 2006). The notion that $C$. carcharias are taking advantage of lowered visibility in Mossel Bay for predation cannot be fully supported here. Before undergoing their ontogenetic dietary shift, juvenile $C$. carcharias feed predominantly upon midwater and bottom-dwelling fish, and as a result are less likely to feed at the surface, and therefore will not need to remain cryptic in lower visibility. As aforementioned, high juvenile C. carcharias abundance in winter may be factored by social learning, it is plausible that inexperienced individuals observe the hunting strategies of larger sharks upon adolescent $A$. pusillus pusillus pups in low visibility.

C. carcharias abundance in Mossel Bay was negatively associated with cloud cover (Fig. 4). It has been demonstrated that increased cloud cover and low water visibility are factors which contribute towards C. carcharias predation success (Pyle et al. 1996; Martin et al. 2005; Hammerschlag et al. 2006). However, our findings suggest that juvenile $C$. carcharias may not yet fully comprehend the benefits of crypticity for predation on pinnipeds, or simply these techniques are not necessary for predating on mid-water and teleost prey. When interpreting these data, it must be appreciated that increased cloud cover and low vertical water visibility can impede on shark sightings, and not all C. carcharias present at Seal Island may be detected by the methods used in this study. Ontogenetic dietary changes in sharks are likely facilitated by adjustments in their hunting abilities (Tricas and McCosker 1984). Further, physical maturation may cause predatory behaviours to change due to improvement in neuromuscular coordination and increased sensory abilities (Meyer 1986; Ciaccio 2008). It is conceivable that maturation improves $C$. carcharias sensory abilities, including visual acuity and electroreception, resulting in larger C. carcharias taking advantage of predation in turbid conditions, particularly in areas surrounding pinniped colonies. Therefore, immature, inexperienced C. carcharias may be prevalent in conditions which compensate for minimal visual acuity such as low cloud cover which increases ambient light levels.

C. carcharias occupy Mossel Bay throughout all months of the year (Fig. 2 and Table 1); in addition to sheltered conditions and an abundance of prey, it is also likely that juvenile sharks select this coastal environment as an anti-predatory strategy (Heithaus 2007). Findlay et al. (2016) found that $C$. carcharias in Mossel Bay were loosely asocial, meaning that clustering of juveniles was possibly due to protection and hunting efficiency through learned behaviour and scavenging techniques, thus supporting the findings in this study. In the absence of adult $C$. carcharias, juveniles can take advantage of the coastal habitat and learn locally adaptive information such as foraging behaviours and predation. Bruce and Bradford (2012) hypothesised that juvenile sharks may learn to feed on passing prey, rather than actively chasing it down, to maximise predatory 
efficiency and minimise energy expenditure. As such, behaviour may have been transmitted culturally, through observing conspecifics in their surroundings, demonstrating how inexperienced sharks can learn from larger sharks in order to develop appropriate hunting strategies.

Nevertheless, the habitat preferences of C. carcharias remain uncertain, and aggregations are believed to be loosely structured by sex and size (Findlay et al. 2016; Hewitt et al. 2017). As wildlife tourism can provide industry-based data sources to investigate species abundance and habitat use (Nazimi et al. 2018), the use of mandatory logbook reporting and citizen science data provides a valuable resource in local population studies. Therefore, studies of movements between different sites would greatly benefit our understanding of $C$. carcharias ecology. For example, future research involving tagging individuals or fin identification (Jewell et al. 2011, 2013) could be combined with previous tracking and sighting data gathered at Mossel Bay during cage-diving trips, which would complement the existing data set. This information may aid in future management strategies, identify the critical habitats of $C$. carcharias and emphasise the value in commercial cage diving operations which can produce international data sets needed to assess global populations of C. carcharias.

The findings from this study indicate that Mossel Bay has a high concentration of both juvenile and female C. carcharias, further strengthening the expectation of female presence in the Southern Cape. It is suggested that, due to the abundance of prey and favourable environmental conditions, Mossel Bay is a nursery ground in the area, providing a crucial habitat for the population of C. carcharias. The potential for social learning among juvenile C. carcharias in Mossel Bay indicates that this habitat may act as a training ground which minimises the costs and risks of individual exploration and provides distinct behavioural advantages such as predation. Ultimately this could be evidence of a $C$. carcharias training ground, and thus, it should be managed appropriately, with the potential to develop management strategies to help safeguard the future of this vulnerable species.

Acknowledgements We would like to extend our appreciation and warm wishes to the White Shark Africa crew on 'Shark Warrior' during 2009-2013 for their participation in enabling the data collection to be accomplished. Gratitude is shown to Elton Polly and Gibbs Kruger for providing the map shapefiles and
2012-2013 datasets. Thanks go to Chelsey Surgenor for assisting in collating and editing the data during her internship at Nottingham Trent University. We would also like to thank Carl Smith for his assistance with R Scripts.

Author's contributions NR, EJ and CF conceptualised the data.

NR, EJ and CK curated the data.

NR, HM and LG analysed the data.

HM, NR and LG led the writing of the manuscript.

All authors contributed critically to the drafts and gave final approval for publication.

Funding This work was partially funded through Nottingham Trent University.

Data availability We agree to archive the data associated with this manuscript should the manuscript be accepted to Nottingham Trent University's Institutional Repository.

\section{Declarations}

Ethics approval Procedures accorded with the standards of Nottingham Trent University's ethics committee. All research methods were permitted and conducted under the South African Department of Environmental Affairs (D.E.A.) and Forestry and Department of Agriculture, Forestry and Fisheries (D.A.F.F) (Permit reference: V1/8/5/1).

Consent All authors consent to participation and publication of this manuscript.

Conflict of interest The authors declare no conflicts of interest.

Open Access This article is licensed under a Creative Commons Attribution 4.0 International License, which permits use, sharing, adaptation, distribution and reproduction in any medium or format, as long as you give appropriate credit to the original author(s) and the source, provide a link to the Creative Commons licence, and indicate if changes were made. The images or other third party material in this article are included in the article's Creative Commons licence, unless indicated otherwise in a credit line to the material. If material is not included in the article's Creative Commons licence and your intended use is not permitted by statutory regulation or exceeds the permitted use, you will need to obtain permission directly from the copyright holder. To view a copy of this licence, visit http://creativecommons.org/licenses/by/4.0/.

\section{References}

Abascal FJ, Quintans M, Ramos-Cartelle A, Mejuto J (2011) Movements and environmental preferences of the shortfin mako, Isurus oxyrinchus, in the southern Pacific Ocean. Mar Biol 158:1175-1184 
Ainley D, Henderson R, Huber H, Boekelheide R, Allen S, McElroy T (1985) Dynamics of white shark/pinniped interactions in the Gulf of the Farallones. South Calif Acad Sci 9: 109-122

Anderson SD, Pyle P (2003) A temporal, sex-specific occurrence pattern among white sharks at the South Farallon Islands, California. Calif Fish Game 89:96-101

Anderson DS, Pyle P, Henderson RP (1996) Tidal height and white shark predation at the Farallon Islands, California. In: Klimley AP, Ainley DG (eds) The biology of Carcharodon carcharias. Academic press, California

Bonfil R, Meÿer M, Scholl MC, Johnson R, O'Brien S, Oosthuizen H, Swanson S, Kotze D, Paterson M (2005) Transoceanic migration, spatial dynamics, and population linkages of white sharks. Science 310:100-103

Boustany AM, Davis SF, Pyle P, Anderson SD, Le Boeuf BJ, Block BA (2002) Expanded niche for white sharks. Nature 415:35-36

Branstetter S (1990) Early life-history implications of selected carcharhinoid and lamnoid sharks of the northwest Atlantic. In: Pratt HL, Gruber SH, Taniuchi T (eds) Elasmobranchs as living resources: advances in the biology, ecology, systematics, and the status of the fisheries Proceedings of the second United States-Japan workshop. NOAA Technical Report NMFS 90:17-28

Bruce BD (2008) The biology and ecology of the white shark, Carcharodon carcharias. In: Sharks of the open ocean: biology, fisheries and conservation. Blackwell Publishing, Oxford

Bruce BD, Bradford RW (2012) Habitat use and spatial dynamics of juvenile White sharks, Carcharodon carcharias, in eastern Australia. In: Domeier ML (ed) Global perspectives on the biology and life history of the white shark. CRC Press, New York

Bruce BD, Stevens JD, Bradford RW (2005) Site fidelity, residence times and home range patterns of white sharks around pinniped colonies. Site fidelity, residence times and home range patterns of white sharks around pinniped colonies. Final report to Department of Environment and Heritage. CSIRO, Hobart, Tas, Australia

Bruce B, Stevens J, Malcolm H (2006) Movements and swimming behaviour of white sharks Carcharodon carcharias in Australian waters. Mar Biol 150:161-172

Carlisle AB, Kim SL, Semmens BX, Madigan DJ, Jorgensen SJ, Perle CR, Anderson SD, Chapple TK, Kanive PE, Block BA (2012) Using stable isotope analysis to understand the migration and trophic ecology of Northeastern Pacific White Sharks (Carcharodon carcharias). PLoS One 7:e30492. https://doi.org/10.1371/journal.pone.0030492

Ciaccio JL (2008) The effects of maturation and experience on the predatory efficiency of the whitespotted bambooshark, Chiloscyllium plagiosum. $\mathrm{PhD}$ thesis, University of Miami

Cliff G, Dudley SF, Jury MR (1996) Catches of white sharks in KwaZulu-Natal, South Africa and environmental influences. In: Klimley AP, Ainley DG (eds) Great white sharks: the biology of Carcharodon carcharias. Academic Press, London

Compagno LJV (1991) Government protection for the great white shark (Carcharodon carcharias) in South Africa. S Afr J Sci 87
Compagno LJV (2001) Sharks of the world: an annotated and illustrated catalogue of shark species known to date. In: Food $\&$ agriculture organisation (FAO) species catalogue for fishery purposes. 2 . Rome

Compagno LJV, Marks MA, Fergusson IK (1997) Threatened fishes of the world: Carcharodon carcharias (Linnaeus, 1758) (Lamnidae). Environ Biol Fish 50:61-62

Dicken ML, Booth AJ (2013) Surveys of white sharks (Carcharodon carcharias) off bathing beaches in Algoa Bay, South Africa. Aust J Mar Freshwat Res 64:530-539

Domeier ML, Nasby-Lucas N (2008) Migration patterns of white sharks Carcharodon carcharias tagged at Guadalupe Island, Mexico, and identification of an eastern Pacific shared offshore foraging area. Mar Ecol Prog Ser 370:221-237

Domeier ML, Nasby-Lucas N (2012) Sex-specific migration patterns and sexual segregation of adult white sharks, Carcharodon carcharias, in the northeastern pacific. In: Domeier ML (ed) Global perspectives on the biology and life history of the white shark. CRC Press, New York

Dudley SF (2012) A review of research on the white shark, Carcharodon carcharias (Linnaeus) Southern Africa. In: Domeier ML (ed) Global perspectives on the biology and life history of the white shark. CRC press, New York

Dulvy NK, Baum JK, Clarke S, Compagno LJ, Cortés E, Domingo A, Fordham S, Fowler SL, Francis MP, Gibson C (2008) You can swim but you can't hide: the global status and conservation of oceanic pelagic sharks and rays. Aquatic Conserv: Mar Freshw Ecosyst 18:459-482

Dulvy NK, Fowler SL, Musick JA, Cavanagh RD, Kyne PM, Harrison LR, Carlson JK, Davidson LN, Fordham SV, Francis MP, Pollock CM, others (2014) Extinction risk and conservation of the world's sharks and rays. Elife 3:e00590

Fallows C, Martin RA, Hammerschlag N (2012) Comparisons between white shark-pinniped interactions at Seal Island (South Africa) with other sites in California (United States). In: Domeier ML (ed) Global perspectives on the biology and life history of the white shark. CRC Press, New York

Fallows C, Fallows M, Hammerschlag N (2016) Effects of lunar phase on predator-prey interactions between white shark (Carcharodon carcharias) and cape fur seals (Arctocephalus pusillus pusillus). Environ Biol Fish 99: 805-812

Ferreira CA, Ferreira TP (1996) Population dynamics of white sharks in South Africa. In: Klimley AP, Ainley DG (eds) Great white sharks: the biology of Carcharodon carcharias. Academic Press, London

Findlay R, Gennari E, Cantor M, Tittensor D (2016) How solitary are white sharks: social interactions or just spatial proximity? Behav Ecol Sociobiol 70:1735-1744

Francis MP (1996) Observations on a pregnant white shark with a review of reproductive biology. In: Klimley AP, Ainley DG (eds) Great white sharks: the biology of Carcharodon carcharias. Academic Press, London

French GCA, Rizzuto S, Sturup M, Inger R, Barker S, van Wyk JH et al (2018) Sex, size and isotopes: cryptic trophic ecology of an apex predator, the white shark Carcharodon carcharias. Mar Biol 165:102

Goldman KJ (1997) Regulation of body temperature in the white shark, Carcharodon carcharias. J Comp Physiol B 167:423429 
Goldman KJ, Anderson SD (1999) Space utilization and swimming depth of white sharks, Carcharodon carcharias, at the south Farallon Islands, Central California. Environ Biol Fish 56:351-364

Graham JB (1983) Heat transfer. In: Webb PW, Weihs D (eds) Fish biomechanics. Praeger Publishers, New York

Gubili C, Johnson R, Gennari E, Oosthuizen W, Kotze D, Meÿer M, Sims D, Jones C, Noble L (2009) Concordance of genetic and fin photo identification in the great white shark, Carcharodon carcharias, off Mossel Bay, South Africa. Mar Biol 156:2199-2207

Guttridge TL, Myrberg AA, Porcher IF, Sims DW, Krause J (2009) The role of learning in shark behavior. Fish Fish 10: 450-469

Guttridge TL, Dijk SV, Stamhuis EJ, Krause J, Gruber SH, Brown C (2012) Social learning in juvenile lemon sharks, Negaprion brevirostris. Anim Cogn 16:55-64

Hammerschlag N, Martin RA, Fallows C (2006) Effects of environmental conditions on predator-prey interactions between white sharks Carcharodon carcharias and cape fur seals Arctocephalus pusillus pusillus at Seal Island, South Africa. Environ Biol Fish 76:341-350

Heithaus MR (2007) Nursery areas as essential shark habitats: a theoretical perspective. Am Fish Soc Symp 50:3-13

Heupel MR, Carlson JK, Simpfendofer CA (2007) Shark nursery areas: concepts, definition, characterization and assumptions. Mar Ecol Prog Ser 337:287-297

Hewitt AM, Kock AA, Booth A, Griffiths CL (2017) Trends in sightings and population structure of white sharks, Carcharodon carcharias, at Seal Island, False Bay, South Africa, and the emigration of sub adult female sharks approaching maturity. Environ Biol Fish 101:39-54

Hubbell G (1996) Using tooth structure to determine the evolutionary history of the white shark. In: Klimley AP (ed) Great white sharks. Elsevier

Hussey NE, McCann HM, Cliff G, Dudley SF, Wintner SP, Fisk AT (2012) Size-based analysis of diet and trophic position of the white shark Carcharodon carcharias in south African waters. In: Domeier ML (ed) Global perspectives on the biology and life history of the white shark. CRC Press, New York

James N, Harrison T (2008) A preliminary survey of the estuaries on the south coast of South Africa, Cape St Blaize, Mossel Bay, Robberg Peninsula, Plettenberg Bay, with particular reference to the fish fauna. Trans R Soc S Afr 63:111-127

Jewell OJD, Wcisel MA, Gennari E, Towner AV, Bester MN, Johnson RL, Singh S (2011) Effects of smart position only (SPOT) tag deployment on white sharks Carcharodon carcharias in South Africa. PLoS One 6:e27242

Jewell OJD, Johnson RL, Gennari E, Bester MN (2013) Fine scale movements and activity areas of white sharks Carcharodon carcharias in Mossel Bay, South Africa. Environ Biol Fish 96:881-894

Johnson R (2003) Behavioural ecology of the white shark (Carcharodon carcharias) at Dyer Island, South Africa. Master's thesis, University of Pretoria
Johnson R, Kock A (2006) South Africa's White shark cagediving industry - is there cause for concern? In: Nel DC, Peshak T (eds) Finding a balance: white shark conservation and recreational safety in the inshore waters of Cape Town, South Africa. WWF, Cape Town, South Africa

Johnson R, Bester MN, Dudley SF, Oosthuizen WH, Meyer M, Hancke L, Gennari E (2009a) Coastal swimming patterns of white sharks Carcharodon carcharias at Mossel Bay, South Africa. Environ Biol Fish 85:189-200

Johnson R, Keswick T, Bester MN, Oosthuizen WH (2009b) Encounters between white sharks and cape fur seals in a shallow channel. Mar Biodivers Rec 2:1-5

Jorgensen SJ, Reeb CA, Chapple TK, Anderson S, Perle C, Van Sommeran SR, Fritz-Cope C, Brown AC, Klimley AP, Block BA (2010) Philopatry and migration of Pacific white sharks. Proc R Soc Biol Sci 277:679-688

Jorgensen SJ, Chapple TK, Anderson S, Hoyos M, Reeb C, Block BA (2012) Connectivity among white shark coastal aggregation areas in the Northeastern Pacific. In: Domeier ML (ed) Global perspectives on the biology and life history of the white shark. CRC Press, New York

Kim SL, Tinker MT, Estes JA, Koch PL (2012) Ontogenetic and among-individual variation in foraging strategies of Northeast Pacific white sharks based on stable isotope analysis. PLoS One 7:e45068

Kime DE, Hews EA (1982) The effect of temperature on steroid biosynthesis by testes of the dogfish, Scyliorhinus caniculus. Comparative biochemistry and physiology. Biochem Mol Biol 4:675-679

Klimley AP (1985) The areal distribution and autoecology of the white shark, Carcharodon carcharias, off the west coast of North America. Bull South Calif Acad Sci 9:15-40

Klimley AP, Anderson SD (1996) Residency patterns of white sharks at the South Farallon Islands, California. In: Klimley AP (ed) Great white sharks. Elsevier

Klimley AP, Le Boeuf BJ, Cantara KM, Richert JE, Davis SF, Van Sommeran S, Kelly JT (2001) The hunting strategy of white sharks Carcharodon carcharias near a seal colony. Mar Biol 138:617-636

Knip DM, Heupel MR, Simpfendorfer CA (2012) Evaluating marine protected areas for the conservation of tropical coastal sharks. Biol Conserv 148:200-209

Kock A (2014) Behavioural ecology of white sharks Carcharodon carcharias in False Bay, South Africa: towards improved management and conservation of a threatened apex predator. Doctoral thesis, University of Cape Town

Kock A, Johnson R (2006) White shark abundance: not a causative factor in numbers of shark bite incidents. In: Finding a balance: white shark conservation and recreational safety in the inshore waters of Cape Town, South Africa

Kock A, O'Riain M, Mauff K, Meÿer M, Kotze D, Griffiths C (2013) Residency, habitat use and sexual segregation of white sharks, Carcharodon carcharias in False Bay, South Africa. PLoS One 8:e55048

Levy D (2016) The environmental factors determining temporal distributions of cetaceans in Mossel Bay, South Africa. Master thesis, University of Cape Town 
Magurran A, Garcia CM (2000) Sex differences in behaviour as an indirect consequence of mating system. J Fish Biol 57:839857

Malcolm H, Bruce BD, Stevens JD (2001) A review of the biology and status of white sharks in Australian waters. Final Report to Environment Australia. CSIRO Marine Research 81

Martin RA, Hammerschlag N, Collier RS, Fallows C (2005) Predatory behaviour of white sharks Carcharodon carcharias at Seal Island, South Africa. J Mar Biol Assoc UK 85:1121-1135

Meyer A (1986) Changes in behavior with increasing experience with a novel prey in fry of the Central American cichlid, Cichlasoma managuense (Teleostei, Cichlidae). Behaviour 98:144-167

Meyer CG, Clark TB, Papastamatiou YP, Whitney NM, Holland KN (2009) Long-term movement patterns of tiger sharks Galeocerdo cuvier in Hawaii. Mar Ecol Prog Ser 381:223235

Nazimi L, Robbins WD, Schilds A, Huveneers C (2018) Comparison of industry-based data to monitor white shark cage-dive tourism. Tour Manag 66:263-273

Pardini AT, Jones CS, Noble LR, Kreiser B, Malcolm H, Bruce BD, Stevens JD, Cliff G, Scholl MC, Francis M, Duffy CAJ, Martin AP (2001) Sex-biased dispersal of great white sharks. Nature 412:139-140

Pouca P, Heinrich D, Huveneers C, Brown C (2020) Social learning in solitary juvenile sharks. Anim Behav 159:21-27

Pyle P, Klimley AP, Anderson SD, Henderson RP (1996) Environmental factors affecting the occurrence and behavior of white sharks at the Farallon Islands, California. In: Klimley AP (ed) Great white sharks. Elsevier

Rigby CL, Barreto R, Carlson J, Fernando D, Fordham S, Francis MP et al (2019) Carcharodon carcharias. The IUCN red list of threatened species, 2019: e.T3855A2878674

Robbins R (2007) Environmental variables affecting the sexual segregation of great white sharks Carcharodon carcharias at the Neptune Islands South Australia. J Fish Biol 70:13501364

Robbins RL, Booth DJ (2012) Seasonal sexual and size segregation of white sharks, Carcharodon carcharias, at the Neptune Islands, South Australia. In: Domeier ML (ed) Global perspectives on the biology and life history of the white shark. CRC Press, New York

Ryklief R, Pistorius P, Johnson R (2014) Spatial and seasonal patterns in sighting rate and life-history composition of the white shark Carcharodon carcharias at Mossel Bay, South Africa. Afr J Mar Sci 36:449-453

Schlaff AM, Heupel MR, Simpfendorfer CA (2014) Influence of environmental factors on shark and ray movement, behaviour and habitat use: a review. Rev Fish Biol Fish 24:1089-1103

Simpfendorfer CA, Heupel M, White W, Dulvy N (2011) The importance of research and public opinion to conservation management of sharks and rays: a synthesis. Aust J Mar Freshwat Res 62:518-527

Sims DW, Nash JP, Morritt D (2001) Movements and activity of male and female dogfish in a tidal sea lough: alternative behavioural strategies and apparent sexual segregation. Mar Biol 139:1165-1175

Skubel RA, Kirtman BP, Fallows C, Hammerschlag N (2018) Patterns of long-term climate variability and predation rates by a marine apex predator, the white shark Carcharodon carcharias. Mar Ecol Prog Ser 587:129-139

Smith SE, Au DW, Show C (1998) Intrinsic rebound potentials of 26 species of Pacific sharks. Aust J Mar Freshwat Res 49: 663-678

Speed CW, Field IC, Meekan MG, Bradshaw CJ (2010) Complexities of coastal shark movements and their implications for management. Mar Ecol Prog Ser 408:275-293

Stevens J, Bonfil R, Dulvy N, Walker P (2000) The effects of fishing on sharks, rays, and chimaeras (chondrichthyans), and the implications for marine ecosystems. ICES J Mar Sci 57:476-494

Strong W, Murphy RC, Bruce BD, Nelson DR (1992) Movements and associated observations of bait-attracted white sharks, Carcharodon carcharias: a preliminary report. Aust J Mar Freshwat Res 43:13-20

Strong WR, Bruce BD, Nelson D, Murphy RD (1996) Population dynamics of white sharks in Spencer Gulf, South Australia. In: Klimley AP, Ainley DG (eds) Great white sharks: ecology and behaviour. Academic Press, London

Tamburin E, Kim SL, Elorriaga-Verplancken FR, Madigan DJ, Hoyos-Padilla M, Sánchez-González A, Hernández-Herrera A, Castillo-Geniz JL, Godinez-Padilla CJ, Galván-Magaña F (2019) Isotopic niche and resource sharing among young sharks (Carcharodon carcharias and Isurus oxyrinchus) in Baja California, Mexico. Mar Ecol Prog Ser 613:107-124

Theberge MM, Dearden P (2006) Detecting a decline in whale shark Rhincodon typus sightings in the Andaman Sea, Thailand, using ecotourist operator-collected data. Oryx 40: 337-342

Towner AV, Underhill LG, Jewell OJD, Smale MJ (2013) Environmental influences on the abundance and sexual composition of white sharks Carcharodon carcharias in Gansbaai, South Africa. PLoS One 8:e71197

Towner AV, Leos-Barajas V, Langrock R, Schick RS, Smale MJ, Kaschke T, Jewell OJD, Papastamatiou YP (2016) Sexspecific and individual preferences for hunting strategies in white sharks. Funct Ecol 30:1397-1407

Tricas TC, McCosker JE (1984) Predatory behaviour of the white shark Carcharodon carcharias with notes on its biology. Proc Calif Acad Sci 43:221-238

Uchida S, Toda M, Teshima K, Yano K (1996) Pregnant white sharks and full-term embryos from Japan. In: Klimley AP, Ainley DG (eds) Great white sharks: ecology and behaviour. Academic Press, London

Wearmouth VJ, Sims DW (2008) Sexual segregation in marine fish, reptiles, birds and mammals: behaviour patterns, mechanisms and conservation implications. Adv Mar Biol 54: $107-170$

Weltz K, Kock AA, Winker H, Attwood C, Sikweyiya M (2013) The influence of environmental variables on the presence of white sharks, Carcharodon carcharias at two popular Cape Town bathing beaches: a generalized additive mixed 
model. PLoS One 8:e68554. https://doi.org/10.1371/journal. pone. 0068554

Weng KC, O'Sullivan JB, Lowe CG, Winkler CE, Dewar H, Block BA (2007) Movements, behavior and habitat preferences of juvenile white sharks Carcharodon carcharias in the eastern Pacific. Mar Ecol Prog Ser 338:211-224

White CF, Lyons K, Jorgensen SJ, O'Sullivan J, Winkler C, Weng KC, Lowe CG (2019) Quantifying habitat selection and variability in habitat suitability for juvenile white sharks. PloS one 14(5): $\mathrm{e} 0214642$

Wintner SP, Cliff G (1999) Age and growth determination of the white shark, Carcharodon carcharias, from the east coast of South Africa. Fish Bull 97:153-169

Wood SN (2011) Fast stable restricted maximum likelihood and marginal likelihood estimation of semiparametric generalized linear models. J R Stat Soc Ser B Stat Methodol 73:3-36
Yates PM, Heupel MR, Tobin AJ, Simpfendorfer CA (2012) Diversity in young shark habitats provides the potential for portfolio effects. Mar Ecol Prog Ser 458:269-281

Zuur AF, Saveliev AA, Leno EN (2012) Zero inflated models and generalized linear mixed models with R. Highland Statistics Ltd, Newburgh

Connor F. White, Kady Lyons, Salvador J. Jorgensen, John O'Sullivan, Chuck Winkler, Kevin C. Weng, Christopher G. Lowe, Heather M. Patterson, (2019) Quantifying habitat selection and variability in habitat suitability for juvenile white sharks. PLOS ONE 14 (5):e0214642

Publisher's note Springer Nature remains neutral with regard to jurisdictional claims in published maps and institutional affiliations. 